\title{
ESL Pedagogy and Certification: Teacher Perceptions and Efficacy
}

\author{
Yune $\operatorname{Tran}^{1}$ \\ ${ }^{1}$ School of Education, George Fox University, Newberg, OR, USA \\ Correspondence: Yune Tran, PhD, School of Education, George Fox University, Newberg, OR, 97132. Tel: \\ 1-503-554-2878. E-mail: ytran@georgefox.edu
}

Received: September 4, 2014

Accepted: September 21, 2014

Online Published: May 29, 2015

doi:10.5539/jel.v4n2p28

URL: http://dx.doi.org/10.5539/jel.v4n2p28

\begin{abstract}
Increasing numbers of English Language Learners (ELLs) in U.S. classrooms have prioritized to building quality teacher education programs so that all teachers have the tools necessary to support their students. National, state, and local mandates have also enacted certain requirements to ensure that ELLs are receiving quality instruction with new language proficiency and content standards. Pressure has pervaded into teacher education programs working to immerse teacher candidates with good pedagogical practices for working with ELLs. This mixed method study on 144 PK-12 teachers with five or less years of experience highlighted the importance of teachers' perceptions and efficacy beliefs in working with ELLs. Findings revealed a statistical significance in efficacy beliefs for teachers with an ESL certification as opposed to teachers without the credentials. Five in-depth cases augmented the finding to support how individual classroom practices exemplified specific ESL pedagogy learned from pre-service contexts to promote more efficacious behaviors.
\end{abstract}

Keywords: teacher efficacy, teacher preparation, English language learners

\section{Introduction}

In the last 30 years, the student demographic population of the United States has not only been an enclave of diverse cultures from around the world but also it has experienced significant changes. One major shift is the number of ELLs enrolled in United States' schools. According to the National Center of Education Statistics (2014), the percentage of public school students in the United States who were ELLs was higher in school year 2011-12 (9.1 percent, or an estimated 4.4 million students) than in 2002-03 (8.7 percent, or an estimated 4.1 million students). As the fastest growing segment of the overall student population, five percent of ELLs also experience difficulty in speaking English. As a highly heterogeneous group of students, ELLs come with varied assets, socio-economic backgrounds, immigration status, and schooling experiences. The language diversity that is represented by ELL students in the United States is also included in this unique population. While the majority of ELLs speak Spanish as their native language, there are over 450 languages that are spoken by ELL students in the United States (Kindler, 2002).

The demographic reality of students from various backgrounds and cultural experiences in the United States has posed unique challenges and opportunities for the teachers who serve them. One such challenge is whether current educational systems are raising standards and building teacher capacity to support ELL needs. The American Association for Employment in Education (2005) found that a certain degree of teacher shortage in the areas of Bilingual Education and English as-a-Second Language (ESL) exist nationwide. According to this report, mainstream teachers who have not acquired any related ESL or ELL training are currently teaching many ELLs. Therefore, addressing pedagogical knowledge of teachers, standards for ELL instruction, and evaluating teacher preparation programs are critical in determining whether teachers are adequately prepared in working with culturally and linguistically diverse students (Irvine, 2003; Tabachnick et al., 1993).

Given these recommendations, the purpose of this research study was to extract how teachers' perceptions of their preparation and efficacy beliefs support their abilities in working with ELLs. Teachers' perceptions were considered through self-perception and self-efficacy theories. The research questions for this study were: 1) What factors influence teachers' perceptions of self-efficacy about teaching ELL students? and 2) What instructional practices are employed by five individual cases to support ELL students? 


\section{Literature Review}

States, districts, and teacher preparation programs vary widely on the specific policies they develop to address the ELL student population and the various capacities they provide to support teachers in meeting students' needs. Past and new studies have documented that to better serve ELLs within the current United States' PK-12 model, teachers need to develop the knowledge, skills, and dispositions to address the linguistic and cultural diversity represented in their classrooms pulling together a framework from: (a) perceptions and efficacy in working with ELLs; (b) standards for ELL instruction; and (c) pedagogical practices for ELLs and teacher knowledge. (Coady et al., 2011; deJong \& Harper, 2005; Lucas et al., 2008; Quezada \& Alfaro, 2012; Tellez \& Waxman, 2005; TESOL; 2010; Wong-Fillmore \& Snow, 2000).

\subsection{Teacher Perceptions and Efficacy}

Some studies have reviewed teachers' beliefs of their pre-service course experiences and in-service training for their effectiveness (Coady et al., 2011; Faez \& Valeo, 2012; Tellez \& Waxman, 2005). Teachers' perceptions affect how they feel about their preparation but also in the instructional decisions they make in meeting the diverse needs of their students (Enderlin-Lampe, 2002). According to historical views of Bem (1972), there are ways in which an individual decides on one's own attitudes and feelings from observing her/his behaviors in various situations, being aware of oneself, and thinking about oneself. These ways of thinking are the basis of self-perception theory used to explain how individuals develop perceptions of themselves and consider most important when thinking about themselves in their appraisals (Hattie, 1992). The attainment of self-perceptions from these salient characteristics would vary; thus, affecting how they perceive preparation experiences for carrying out instructional behaviors.

In addition, self-efficacy theory was used to understand teachers' self-reported responses in controlling situations and employing instructional practices for ELLs. Research has suggested that a positive relationship between instructional effectiveness and self-efficacy exists when teachers feel confident about their craft and alter their behaviors to benefit student learning (Goddard et al., 2004; Woolfolk et al., 1990). Teacher self-efficacy is rooted in Bandura's (1997) social cognitive theory to include four sources of efficacy expectations: mastery experiences; physiological and emotional states; vicarious experiences; and social persuasion. Mastery experiences are powerful sources of efficacy that raise teaching beliefs while the school setting serves as a social influence to increase one's efficacy especially for new teachers (Woolfolk \& Spero, 2005).

Moreover, strong teacher efficacy is related to effective classroom behaviors, (Stein \& Wang, 1988) positive student outcomes, (Woolfolk \& Spero, 2005) and the perceived ability to work with students from diverse backgrounds including ELL students. Studies have found that perceptions of instructional efficacy among teachers are affected by more specialized certification and teaching experience (Gandara et al., 2005; Goddard et al., 2004; Tshannen-Moran et al., 1998). For teachers with high self-efficacy, they often perceive difficult situations and tasks as something to be mastered rather than avoiding them. As such, they are more likely to organize their own behaviors to affect their perspectives in teaching ELL students. Despite the role that teacher efficacy plays in the classroom, significant literature has indicated that a number of teachers believed they are not prepared to serve the specific needs of ELLs (Gandara et al., 2005; Karabenick \& Noda, 2004; Taylor \& Sobel, 2001); therefore, it is particular important to address the standards and instructional models designed to meet this population.

\subsection{Standards for ELL Instruction in the United States}

Examining what standards are in place at the state and national level helps determine the process in which teachers obtain the necessary qualifications in working with ELLs. The National Association of Bilingual Education (NABE) and the Teachers of English to Speakers of Other Languages (TESOL) are two professional organizations whose focus is primarily on the education of ELL students in the Unite States with standards for the preparation of teachers. NABE's guidelines suggest adherence to the general standards of the National Council for Accreditation of Teacher Education (NCATE) whereas the TESOL's guidelines (2010) developed in conjunction with NCATE are designed for initial teacher preparation and include the following five domains: (a) language, (b) culture, (c) planning, implementation, and managing instruction, (d) assessment, and (e) professionalism. The revised NCATE (2009) standards stressed the need for teacher candidates to be prepared in these areas in meeting ELLs' academic and linguistic needs. Finally, the standards within the Council of Chief State School Officer Interstate Teacher Assessment and Support Consortium (CCSSO InTASC, 2011) require that teacher candidates show competencies in content matter, human development, differentiation, and methodology related to language domains, scaffolding techniques, and delivering instruction so that students' needs are met and ELLs acquire content and language proficiency. 
As ELLs scatter across PK-12 classrooms in the United States, public school teachers began working with these students - some for the very first time making the demographic reality more apparent. Responsibility shifted from ESL and bilingual teachers who traditionally taught ELLs to mainstream classroom teachers in meeting the needs of all students (Kaplan \& Leckie, 2009). However, many teachers did not feel that they have the appropriate training to serve ELLs or were adequately prepared to meet the linguistic, academic, and diverse needs of this student population (Combs et al., 2005). Therefore, as schools and districts experience the changing demographics of ELLs coupled with the educational climate of enhancing inclusionary practices rather than separate specialized programs, it imperative that mainstream teachers develop additional linguistic and cultural knowledge with practical applications in curriculum planning, pedagogy, and assessment to work effectively with students so that ELLs can achieve academic parity with their native-English peers (Ballantyne et al., 2008; deJong \& Harper, 2005).

In promoting teachers' sense of efficacy, Grant and Wong (2003) reported certain recommendations provided by the Center for Research on Education, Diversity, and Excellence (CREDE) that are essential in helping teachers establish good teaching practices to enhance ELLs' educational experiences and success. The five CREDE standards include: joint productivity, language development, making meaning for students by contextualizing teaching and curriculum, teaching complex thinking, and teaching through conversation (CREDE, 2002).

The first CREDE standard, joint productivity, involves teachers designing instruction that focuses on experts and novices working together to achieve a common product or goal. The second CREDE standard is language development through meaningful and purposeful conversations that promote listening, speaking, reading, and writing across the curriculum and through the school day. The third CREDE standard is making meaning for students by contextualizing teaching and curriculum in the experiences and skills of students' homes, communities, and schools by engaging students, building background, and connecting with prior experiences. The fourth CREDE standard, teaching complex thinking, stresses the importance of developing higher-order thinking skills and challenging activities for ELLs rather than repetition and rote memorization. The final CREDE standard, teaching through conversation, emphasizes instructional conversations where students have opportunities to share their ideas and dialogue about academic content with their peers.

While Grant and Wong (2003) emphasized that these standards provide a framework of possibilities for teacher education programs can consider, they are not exhaustive or insure that ELLs' needs are sufficiently met. In-service teachers need in-depth opportunities to strengthen their pedagogical skills to develop the necessary understandings in teaching both language and content while improving cultural competence and attitudes to support ELLs (Antunez, 2002; Ballantyne et al., 2008).

\subsection{Teaching Methodologies for ELLs}

Given the growing numbers of ELLs in mainstream classes across the country, the ESL field has moved into the direction of special language-related knowledge and pedagogical competence that all mainstream teachers need to effectively teach ELLs. First, a foundation of second language acquisition and its set of principles are discussed in serving ELLs in mainstream classes. Second, linguistic pedagogical practices and scaffolding techniques are examined as teachers support ELLs in mainstream classroom (Lucas et al., 2008).

Successful teachers of ELLs must draw on a broad range of knowledge; however, one of the most critical is an understanding of the established principles of second language learning (deJong \& Harper, 2005; Samway \& McKeon, 2007). Since ELLs are learning English and content simultaneously, they need teachers who are best equipped with the knowledge of key principles in second language acquisition. Thus, the essential understandings that are relevant to this second language learning include: (a) conversational language proficiency and academic language proficiency are fundamentally different (Cummins, 2000); (b) second language learners need access to comprehensible input that is beyond their level of competence (Krashen, 1985; 2003); (c) ELLs need opportunities for social interaction to foster their development in conversational and academic English (Vygostky, 1978; Wong-Fillmore \& Snow, 2005); (d) ELLs who are proficient in their native language are more likely to achieve parity with native-English speaking peers than those who are less proficient in their native language (Cummins, 2000); (e) safe, supportive classroom environments that reduce the affective filter are crucial in promoting ELLs second language learning (Krashen, 2003; Verplaetse \& Migliacci, 2008); and (f) explicit instruction on linguistic form and function is important for second language development (Schleppergrell, 2004).

Linguistic pedagogical practices that teachers need to accommodate their ELLs include strategies of wait time, enhanced vocabulary instruction, the use of visuals, and scaffolding techniques that are essential for teachers as they integrate academic content with purposeful language instruction. By utilizing the target language, teachers 
teach academic subjects to students while taking into consideration their varied language needs. Thus, content becomes the vehicle for teaching students their second language (Lucas et al., 2008; Waqui, 2008) including instructional adaptations such as scaffolds to make in order to make content comprehensible to ELLs (Echevarria et al., 2004). This strategy is drawn from Wood, Bruner and Ross (1976) and Vygotsky's zone of proximal development (1978) where teachers provide temporary supports to help learners carry out challenging academic tasks that they are unable to do alone. Walqui (2008) noted that scaffolding is a means through which teachers "amplify and enrich the linguistic and extralinguistic context" allowing learners to successfully obtain concepts and skills (p. 107). Lucas et al. (2008) suggested that for teachers to scaffold learning effectively, they must have three types of pedagogical expertise: familiarity with students' linguistic and academic backgrounds; and understanding of the language demands that are conducive to the learning tasks that are expected; and skills for using appropriate scaffolding so that ELLs can participate successfully in those tasks.

In addition to the specialized language skills from above, Freeman and Johnson (1998) had broadened the field to address what teachers of ELLs should know and be able to do. They identified key areas of knowledge to include in the discipline the personal and social contexts of teaching itself within theory and practice by posing three broad families of the knowledge-base: the nature of the teacher-learner; the nature of schools and schooling; and the nature of teaching which includes pedagogical subject matter, content, and learning.

The first domain recognizes that in the context of second language teaching, teacher learning is primarily concerned with teachers as learners themselves (Kennedy, 1991). In the second domain, understanding the social and cultural contexts of schools and schooling is critical in establishing the knowledge-base for teaching of ELLs such as how teachers are socialized into their roles during their first years on the job and as they receive continuing education through professional development seminars in and through school (Freeman \& Johnson, 1998). Schooling, however, draws on various constructs as it gains value and meaning for participants over time. Here, the domain draws from Lortie's (1975) concept of the apprenticeship of observation, which accounts for the way teachers develop their vision for teaching while being socialized as students throughout their careers. Crucial is the idea of a "curricular vision" where teachers develop a sense of where they are and where they want their students (Feiman-Nemser, 2001). Finally, the last domain draws on the pedagogical process of teaching and learning. Derived from the theoretical framework of Shulman's (1986) perspective, teachers' practice is drawn from a knowledge base to include: (a) subject matter content knowledge, (b) pedagogical content knowledge, and (c) curricular knowledge. From this perspective, pedagogical content knowledge (PCK) is most critical because of the interaction between content and pedagogy where teachers learn to organize, represent, and adapt curriculum to serve the varied abilities and diverse interests of students (Grossman, 1990; Shulman, 1986, 1987).

\section{Methodology}

This research employed a mixed method design called Concurrent Triangulation Strategy (Creswell, 2003) composed of a quantitative survey and case studies (Merriam, 1998; Yin, 2008). In the quantitative phase, the researcher created an adapted survey for new teachers (those with five or fewer years of experience) to address teachers' knowledge and perceptions in their pre-service course experience as well as teachers' efficacy beliefs in relation to ESL methodologies, multicultural education, and cultural/linguistic diversity. The researcher obtained electronic permission to adapt and extend from the original questionnaire (K. Fuller, Personal Communication, November 19,2010) that surveyed alternatively certified teachers' attitudes for ELLs. The new instrument was developed with open and closed-ended items including 30 likert perception and efficacy items (rated using a six-point scale) that were organized into four categories: culture, teaching strategies, teaching behaviors, and assessment practices respectively. Internal consistency reliability was calculated for preparedness items as 0.979 and efficacy items as 0.9782 using Cronbach's alpha in SPSS demonstrating a high inter-correlation between items. Some closed-ended items on the survey included: teachers' biographical information (age, gender, ethnicity); type of teaching certification(s) held (i.e. ESL, special endorsements, etc.); years of teaching experience; nature of teaching assignment; school locale; percentage of students who were identified as ELLs; teachers' ESL/ELL coursework experience; the amount of ESL/ELL training received in professional development; and teachers' efficacy beliefs in how they felt other staff members at school improved their skills for instructing ELLs. Open-ended items on the questionnaire included questions about valuable training experiences, areas that were lacking from teacher preparation, and beliefs about support from school personnel that improved their instruction for ELLs. The qualitative phase included in-depth case studies with a select group of teachers in interviews and classroom observations so that richer details of teachers' experiences can be recorded in a real-life context resulting in more descriptive data (Merriam, 1998; Yin, 2008). 


\subsection{Data Sources}

Eligible participants in the study included teachers from two local school districts in central Texas with five or fewer years of experience. One district enrolled over 20,000 students and the other an approximate 6,000 students. These districts provided a fitting backdrop to the study due to the differences in their student body; the context of their community; and the overall number of ELL student population represented that mirrored state and national averages. One district served a student population of over 20,000 students but only $10 \%$ of their students were identified as ELLs whereas the second district served a student population of over 6,500 but approximately two-thirds of their students were identified as ELLs. Furthermore, these districts were part of a larger consortium of schools in the region engaged in monthly conversations regarding best pedagogical practices for ELLs given the influx of students. The questionnaire that was used included an online email invitation to eligible participants in both districts and narrowed to in-service teachers who had five or less years of experience. Survey Monkey and SPSS 19 for Windows Vista included features that allowed the researcher to analyze all quantitative data. Further analysis included descriptive and inferential statistics while percentages were used to describe closed ended items such as: participants' demographic profile, years of teaching experience, type of certification held, the teacher's main role at the school, the school enrollment size, school locale, the number of ELLs enrolled in the school, whether teacher's had ELL students, and participation in activities that influenced their work with ELLs. Means and Standard Deviations were used for the following subscales: (a) perception of teacher's preparedness from course experiences and (b) efficacy beliefs in teaching ELLs.

Once the 144 completed surveys were returned (16\% retrieval rate), 20 participant's names that had consented to the second phase of the research were gathered. Of these names, six teachers were chosen to conduct in-depth case studies. The researcher narrowed the final sample to five participants given similarity in two cases. Of the five teachers selected, considerations of independent variables included: age, gender, ethnicity, contextual factors related to current place of employment, number or ELL students in their classrooms, teaching certification, and self-assessed perception/efficacy ratings. Demographic and teaching profiles that were represented within the five PK-12 cases included: three females, two males, two-identified Latina, three-identified Caucasian ranging from the ages between 24-35, two kindergarten classrooms, one fourth-grade classroom, one sixth grade language-arts, and one high school science class. The chart following details the profiles of each case including teachers' self-reported ratings of perception and efficacy related to teaching ELLs.

Table 1. Analysis of each teacher case

\begin{tabular}{|c|c|c|c|c|c|c|}
\hline & & & & & Self-rated & \\
\hline Teacher & Profile & $\begin{array}{l}\text { ELL } \\
\text { Population }\end{array}$ & $\begin{array}{l}\text { ESL } \\
\text { Certification }\end{array}$ & $\begin{array}{l}\text { Pedagogical Strength: } \\
\text { CREDE } \\
\text { Standard that Teacher } \\
\text { Supported }\end{array}$ & $\begin{array}{l}\text { Perception } \\
\text { Ratings } \\
\text { (Prepared-Very } \\
\text { Well } \\
\text { Prepared Items) }\end{array}$ & $\begin{array}{l}\text { Self-rated } \\
\text { Efficacy Ratings } \\
\text { (Effective-Very } \\
\text { Effective Items) }\end{array}$ \\
\hline $\begin{array}{l}\text { Antonia } \\
\text { Perez }\end{array}$ & $\begin{array}{lr}30 \text { year-old Latina female, } \\
\text { fours years } & \text { experience, } \\
\text { Kindergarten } & \text { Spanish } \\
\text { bilingual, } & \text { traditional } \\
\text { undergraduate } & \end{array}$ & $\begin{array}{l}19 \% \\
\text { campus } \\
\text { All ELL } \\
\text { students }\end{array}$ & Yes & $\begin{array}{l}3 \text { : making meaning for } \\
\text { students by } \\
\text { contextualizing teaching } \\
\text { and curriculum } \\
\text { comprehensible input }\end{array}$ & $\begin{array}{l}\text { Fairly well } \\
\text { prepared-5 } \\
\text { Well } \\
\text { prepared-24 }\end{array}$ & $\begin{array}{l}\text { Effective-29 } \\
\text { Very Effective-1 }\end{array}$ \\
\hline $\begin{array}{l}\text { Matthew } \\
\text { Thompson }\end{array}$ & $\begin{array}{l}24 \text { year-old Caucasian } \\
\text { male, } 1^{\text {st }} \text { year teacher, } 9^{\text {th }} \\
\text { grade science, traditional } \\
\text { undergraduate }\end{array}$ & $\begin{array}{l}2 \% \text { campus } \\
3 \quad \text { ELL } \\
\text { students in } \\
\text { classroom }\end{array}$ & No & $\begin{array}{l}\text { 4: teaching complex } \\
\text { thinking }\end{array}$ & $\begin{array}{l}\text { Prepared-2 } \\
\text { Fairly well } \\
\text { prepared-4 } \\
\text { Well } \\
\text { prepared-4 } \\
\text { Very well } \\
\text { prepared-13 }\end{array}$ & $\begin{array}{l}\text { Effective-3 } \\
\text { Very Effective-5 }\end{array}$ \\
\hline
\end{tabular}




\begin{tabular}{|c|c|c|c|c|c|c|}
\hline \multirow[b]{2}{*}{$\begin{array}{l}\text { Thelma } \\
\text { Smith }\end{array}$} & \multirow[b]{2}{*}{$\begin{array}{l}35 \text { year-old } \text { Caucasian } \\
\text { female, five } r \text { years } \\
\text { experience, } 6^{\text {th }} \text { grade } \\
\text { language -arts, traditional } \\
\text { undergraduate }\end{array}$} & & \multirow[b]{2}{*}{ Yes } & \multirow[b]{2}{*}{$\begin{array}{l}2: \quad \text { language } \\
\text { development } \\
\text { 5: teaching through } \\
\text { conversations }\end{array}$} & \multicolumn{2}{|l|}{ Prepared-2 } \\
\hline & & $\begin{array}{l}27.3 \% \\
\text { campus } \\
4 \quad \text { ELL } \\
\text { students }\end{array}$ & & & $\begin{array}{l}\text { Fairly well } \\
\text { prepared-6 } \\
\text { Well } \\
\text { prepared-18 }\end{array}$ & $\begin{array}{l}\text { Effective-15 } \\
\text { Very Effective-7 }\end{array}$ \\
\hline $\begin{array}{l}\text { Timothy } \\
\text { Jones }\end{array}$ & $\begin{array}{l}25 \text { year-old Caucasian } \\
\text { male, } 1^{\text {st }} \text { year teacher, } \\
\text { fourth grade math, } \\
\text { alternative program }\end{array}$ & $\begin{array}{l}34 \% \\
\text { campus } \\
18 \quad \text { ELL } \\
\text { students }\end{array}$ & $\begin{array}{l}\text { No, but has } \\
\text { bilingual }\end{array}$ & 1: joint productivity & $\begin{array}{l}\text { Prepared -12 } \\
\text { Fairly } \\
\text { prepared-6 }\end{array}$ & $\begin{array}{l}\text { Effective-16 } \\
\text { Very Effective-1 }\end{array}$ \\
\hline $\begin{array}{l}\text { Lulu } \\
\text { Martinez }\end{array}$ & $\begin{array}{l}24 \text { year-old Latina female, } \\
\text { 1st year teacher, } \\
\text { kindergarten, traditional } \\
\text { undergraduate }\end{array}$ & $\begin{array}{l}7.2 \% \\
\text { campus } \\
1 \quad \text { ELL } \\
\text { student }\end{array}$ & No & $\begin{array}{l}\text { 3: making meaning for } \\
\text { students by } \\
\text { contextualizing teaching } \\
\text { and curriculum } \\
\text { comprehensible input }\end{array}$ & $\begin{array}{l}\text { Fairly well } \\
\text { prepared-11 } \\
\text { Well } \\
\text { prepared-3 } \\
\text { Very well } \\
\text { prepared-16 }\end{array}$ & $\begin{array}{l}\text { Very } \\
\text { Effective-30 }\end{array}$ \\
\hline
\end{tabular}

Note. Pseudonyms used for all teachers.

Sources of data from each case also included interview transcriptions and field notes from classroom observations that averaged from one to two hours in length depending on the teacher's grade level and/or content-area taught. Qualitative data were analyzed and coded by the researcher. The NVivo software program was used to input data to allow more manageable analysis given its labeling and coding features. Codes that were used were derived from the existing literature regarding instructional practices for ELLs from Abedi, (2003); CREDE (2002); deJong and Harper (2005); Verplaetse and Migliacci (2008) and Wong-Fillmore and Snow (2005) into these variations: prior knowledge, vocabulary important to ELLs, slowed speech, hands-on activities, specific learning related to specific coursework, professional development, and cultural understanding. Themes that were generated evolved around specific methodologies based on the CREDE's Standards (2002) to highlight where teachers showed strengths around the consistency of implementing various ESL strategies.

\section{Results}

Both quantitative (descriptive and inferential statistics) and qualitative procedures were carried out to determine whether teachers' knowledge affect instructional decisions made for ELLs and whether their efficacy beliefs aligned with the strategies that were employed in the classroom for meeting the needs of ELL students. The use of surveys, interviews, classroom observations, and field notes triangulated the data to provide analysis. Mean differences for teacher perception and efficacy items are indicated in the following table revealing higher efficacy ratings overall. Additional findings follow to detail the impact of an ESL certification: showing a statistical significance in efficacy beliefs for teachers who held an ESL certification as opposed to those who did not. The finding was augmented from individual cases to highlight specific ESL practices acquired from preparation experiences that promoted their efficacy in working with ELL students.

Table 2. Mean and standard deviation for perception of preparedness \& efficacy belief items

\begin{tabular}{lllll}
\hline Perception Items $N=144$ & $\begin{array}{l}\text { Perception } \\
\text { Mean }\end{array}$ & $\begin{array}{l}\text { Std. } \\
\text { Deviation }\end{array}$ & $\begin{array}{l}\text { Efficacy } \\
\text { Mean }\end{array}$ & $\begin{array}{l}\text { Std. } \\
\text { Deviation }\end{array}$ \\
\hline $\begin{array}{l}\text { Develop a deep sense of cultural knowledge. } \\
\text { Develop an understanding and sensitivity that appreciates differences }\end{array}$ & 3.3050 & 1.40379 & 4.3882 & 1.22566 \\
as well as similarities. & & 1.31155 & 4.8023 & 1.04959 \\
Incorporate cultural values into the curriculum. & 3.4965 & 1.38680 & 4.3372 & 1.17434 \\
Include student's home cultures into the classroom. & 3.3475 & 1.49277 & 4.1860 & 1.25099 \\
Develop relationships with families. & 3.7801 & 1.53573 & 4.3953 & 1.22982 \\
Engage families in educational experiences of their students. & 3.5106 & 1.53817 & 4.1047 & 1.27445 \\
\hline
\end{tabular}


Encourage students to use their native language.

Tap into student's prior knowledge.

Use realia (real--life) objects as a teaching strategy.

Help students connect new knowledge to prior experiences.

Use a variety of vocabulary strategies in lessons.

Use visuals, nonverbal cues, demonstrations, and graphic aids as teaching tools.

Use a variety of technologies to assist in student's understanding. Incorporate total physical response (TPR) methods in teaching.

Establish opportunities for students to interact.

Establish opportunities for students to speak to reinforce learning.

Adjust the speed of English speech delivery.

Model appropriate English use.

Provide oral directions that are clear and appropriate.

Create opportunities for students to practice their oral English.

Create opportunities for students to practice their written English.

Encourage all students to elaborate on their responses.

Scaffold instruction to help students understand concepts.

Use a variety of hands-on activities.

Incorporate student's responses into lessons.

Provide appropriate wait time for students to respond.

Encourage students to respond using higher order questioning.

Provide appropriate accommodations based on student's

language proficiency.

Provide various formats of assessments according to student's intelligence and/or learning style.

Use a variety of technologies as alternative assessments.

$\begin{array}{llll}3.0922 & 1.61644 & 3.8837 & 1.45859 \\ 4.1915 & 1.45364 & 4.7326 & 1.03383 \\ 4.2695 & 1.45837 & 4.7558 & 1.11604 \\ 4.3404 & 1.38270 & 4.8353 & 1.04480 \\ 4.0780 & 1.37877 & 4.5465 & 1.19466 \\ 4.5035 & 1.39194 & 4.7907 & 1.06402\end{array}$

4.1631

$1.38164 \quad 4.6163$

1.11849

3.5390

1.56076

4.2558

1.37358

4.4468

$1.33858 \quad 5.0116$

.95171

4.2624

$1.27417 \quad 4.8353$

1.07844

3.6596

1.39811

4.5116

1.10341

4.3121

1.41993

4.9882

1.07453

4.3262

1.34428

4.8372

.93129

4.1418

1.38658

4.8118

1.04077

4.0426

1.46323

4.5581

1.22335

4.1631

1.40216

4.7209

1.15454

4.1844

1.44223

4.6353

1.08942

4.5035

1.38164

4.9176

1.02599

4.1277

1.40332

4.6024

1.20911

4.4539

1.38087

4.7529

1.07909

4.1418

1.37623

4.5412

1.19077

3.6170

1.46219

4.4048

1.16287

3.9007

1.43579

4.4471

1.27714

1.45886

4.1905

1.32152

\subsection{Significance of an ESL Certification}

The researcher ran this variable to that of the 30 efficacy items using SPSS software. An Independent Samples T-Test shown in Table Two reveled a difference in self-reported sense of efficacy with respect to instructing ELLs between teachers who held an ESL certification as opposed to those who did not have the certification. Statistically significance was shown on as many of 14 items on the scale with teacher's efficacy beliefs when a standard P-value is at the .005 level. However, the P-value with the strongest statistically significant difference (2-tailed that being closest to .005) between the two groups included teacher's beliefs to: use a variety of vocabulary strategies in lessons; adjust the speed of English speech delivery; incorporate total physical response (TPR) methods into teaching; provide oral directions that are clear and appropriate; and create opportunities for students to practice their written English (see Table 3).

Table 3. Independent samples T-test comparison

\begin{tabular}{|c|c|c|c|c|c|}
\hline Efficacy Item & $\mathrm{F}$ & Sig. & $\mathrm{t}$ & $\mathrm{df}$ & Sig. (2-tailed) \\
\hline \multirow[t]{2}{*}{ Use a variety of vocabulary strategies in lessons. } & 4.839 & .031 & -2.609 & 84 & .011 \\
\hline & & & -2.785 & 78.160 & .007 \\
\hline Incorporate total physical response (TPR) methods in teaching. & 4.205 & 043 & -3.029 & 84 & 003 \\
\hline
\end{tabular}




\begin{tabular}{|c|c|c|c|c|c|}
\hline & & & -3.270 & 79.897 & .002 \\
\hline \multirow[t]{2}{*}{ Adjust the speed of English speech delivery. } & 10.960 & .001 & -2.870 & 84 & .005 \\
\hline & & & -3.256 & 84.000 & .002 \\
\hline \multirow[t]{2}{*}{ Provide oral directions that are clear and appropriate. } & 2.550 & .114 & -3.066 & 84 & .003 \\
\hline & & & -3.327 & 80.643 & .001 \\
\hline \multirow[t]{2}{*}{ Create opportunities for students to practice their written English } & 6.064 & .016 & -3.087 & 84 & .003 \\
\hline & & & -3.366 & 81.244 & .001 \\
\hline
\end{tabular}

Note. Statistical significance at the P-value of .005.

Results from the above table were further supplemented by mean differences in Table 4 to show that efficacy beliefs were higher for teachers who held an ESL certification as opposed to those who did not have the certification.

Table 4. ESL certification and efficacy beliefs

\begin{tabular}{|c|c|c|c|c|}
\hline Efficacy Item & ESL & $\mathrm{N}$ & Mean & Std. Deviation \\
\hline \multirow{2}{*}{ Develop a deep sense of cultural knowledge. } & $\mathrm{NO}$ & 54 & 4.1667 & 1.29949 \\
\hline & YES & 31 & 4.7742 & .99028 \\
\hline \multirow{2}{*}{ Encourage students to use their native language. } & NO & 54 & 3.5926 & 1.43433 \\
\hline & YES & 32 & 4.3750 & 1.38541 \\
\hline \multirow{2}{*}{ Tap into student's prior knowledge. } & NO & 54 & 4.5370 & 1.12791 \\
\hline & YES & 32 & 5.0625 & .75935 \\
\hline \multirow{2}{*}{ Use a variety of vocabulary strategies in lessons. } & NO & 54 & 4.2963 & 1.25337 \\
\hline & YES & 32 & 4.9688 & .96668 \\
\hline \multirow{2}{*}{ Incorporate total physical response (TPR) methods in teaching. } & NO & 54 & 3.9259 & 1.43871 \\
\hline & YES & 32 & 4.8125 & 1.06066 \\
\hline \multirow{2}{*}{ Establish opportunities for students to interact. } & NO & 54 & 4.8333 & 1.02331 \\
\hline & YES & 32 & 5.3125 & .73780 \\
\hline \multirow{2}{*}{ Establish opportunities for students to speak to reinforce learning. } & NO & 53 & 4.6604 & 1.10842 \\
\hline & YES & 32 & 5.1250 & .97551 \\
\hline \multirow{2}{*}{ Adjust the speed of English speech delivery. } & NO & 54 & 4.2593 & 1.21601 \\
\hline & YES & 32 & 4.9375 & .71561 \\
\hline \multirow{2}{*}{ Provide oral directions that are clear and appropriate. } & NO & 54 & 4.6111 & .97935 \\
\hline & YES & 32 & 5.2188 & .70639 \\
\hline \multirow{2}{*}{ Create opportunities for students to practice their oral English. } & NO & 54 & 4.6296 & 1.10396 \\
\hline & YES & 31 & 5.1290 & .84624 \\
\hline \multirow{2}{*}{ Create opportunities for students to practice their written English. } & NO & 54 & 4.2593 & 1.29127 \\
\hline & YES & 32 & 5.0625 & .91361 \\
\hline \multirow{2}{*}{ Scaffold instruction to help students understand concepts. } & NO & 54 & 4.4630 & 1.14452 \\
\hline & YES & 31 & 4.9355 & .92864 \\
\hline \multirow{2}{*}{ Provide appropriate wait time for students to respond. } & NO & 54 & 4.5556 & 1.12714 \\
\hline & YES & 31 & 5.0968 & .90755 \\
\hline \multicolumn{2}{|c|}{ Provide appropriate accommodations based on student's languageNO } & 53 & 4.2075 & 1.19869 \\
\hline proficiency. & YES & 31 & 4.7419 & 1.03175 \\
\hline
\end{tabular}




\subsection{Preparation Experiences that Influenced Specific ESL Pedagogy among Cases}

Additionally, the analysis from the individual cases of: Timothy, Lulu, Antonia, Thelma, and Matthew (pseudonyms) provided a lens to determine how the benefits of preparation experiences promoted specific ESL methodologies that were utilized in the classrooms while promoting teachers' efficacy beliefs overall. The teacher profile chart from Table 1 previously summarized characteristics of individual cases to include: demographics, percentage and number of ELL students, ESL certification, self-rated perceptions and efficacy beliefs, and finally, the CREDE standard where each teacher reasonably showed use of ESL strategies that were utilized in classroom practices to influence ELL's learning. These methods ranged from slowed speech, repetition, highlighted vocabulary, peer interaction, visual scaffolds, and clarification of academic learning tasks. In identifying which CREDE standard to highlight for each case, the researcher used themes from interviews and classroom observations to connect how content learned from previous course experiences translated into specific ESL strategies that were exemplified in the classroom to reveal teachers' understandings of ESL content pedagogical knowledge.

The case of Antonia Perez indicated an asset with CREDE standard three in making meaning for students by contextualizing teaching and curriculum for comprehensible input. Her emphasis on vocabulary, the use of visuals, repetition, and appropriate speech were evident both in the observation and interview when she noted that particular skills learned from college are necessary when teaching ELLs:

And, I took about 20 ESL college credit courses. Those classes helped me a lot to understand how I am helping the children...I think one of the main things is that you have to understand, you have to make the kids feel comfortable. You know, just make the child express however they can. It can be either with movement, with drawings even in their own language. We use speaking, we try to help the use their sounds, pronounce, and teach them how to linguistically say the words if it's not their first language... We also do it with a lot of visuals, a lot prompting, and repetition. We have to go slow, you can not go too fast with the children. You have them all different ways: to look at it to, to taste it, to feel it, to touch it especially since we don't want to speak Spanish so we have to really emphasize vocabulary which it the main goal (Antonia Perez, Interview, March 30, 2011).

Here, Antonia recalled the use of explicit language structures, visual aids, and extensive modeling as helpful exercises to help students learn, build, and develop academic English. Her passion for working with ELLs transpired from obtaining initial licensure of an ESL certification into a classroom where she felt confident and effective for promoting ELL's success. She supported CREDE standard one in joint productivity well through the use of scaffolds to build student's academic language while utilizing peer interaction noted in a variety of partnering activities throughout the science lesson from exploratory to building vocabulary, and finally, culminating into with paired journal activity for all students to acquire English meaningfully.

Similarly, for Thelma Smith who supported CREDE standard two in language development and CREDE standard five in teaching through conversation by emphasizing the importance of teachers who understand the language acquisition process with adequate lesson preparation to embed a variety of strategies such as native language support. She articulated this point saying,

You have to be prepared. I mean if your lesson is not prepared to reach ELL kids, it's not going to do that. It's very explicit, the instruction... One of the things that works really well in my class is I have kids that are varying levels of ELLs, some of them having been exited already but they still struggle and then I have the newcomers. I'll pair them up and I allow them to talk in my class and even communicate quietly to help each other with directions and instructions and that really helps them. They need that support and it makes them feel confident in the classroom (Thelma Smith, Interview, March 24, 2011).

Thelma expressed from above that she had the profound ability to accommodate instruction for the varied proficiency levels of ELLs, to differentiate for all her students, and the impact of purposeful instruction for ELLs. Thelma also specified how coursework experiences affected her abilities in teaching ELLs in the comment below.

Yes, at the university, we had an actual class where we had to go in and work with struggling readers and we did that in Parkside ISD (pseudonym)...It was a great class and that really prepared me (for ELLs) (Thelma Smith, Personal Communication, March 24, 2011).

These remarks represent the significance of quality preparation experiences in building teacher's pedagogical toolboxes especially for linguistically and culturally diverse learners. Additionally, Thelma's self-reported perception and efficacy ratings revealed the significance of pre-service coursework in building her capacity to work successfully with ELL students. Thelma indicated that the university well prepared her in over 18 items 
with attention to: tap into student's prior knowledge; use visuals, nonverbal cues, demonstrations, and graphic aids as teaching tools; adjust the speed of English speech delivery; create opportunities for students to practice their oral English; scaffold instruction to help students understand concepts; provide appropriate wait time for students to respond; and provide appropriate accommodations based on student's language proficiency-teaching practices that aligned well to CREDE standards two and five.

Evident in Matthew Thompson's case was his meticulous use of CREDE standard four in teaching complex thinking as he stressed the importance of developing higher-order thinking skills and challenging activities for ELLs rather than repetition and rote memorization. He consistently assisted ELL's understanding of the lesson objective through think a-louds and encouraged higher-order thinking. A variety of other techniques were also used according to the varied proficiency levels of his ELLs as well as providing them with a platform to inquire, challenge, and make connections to cultural experiences and real-life applications.

The highest rated efficacy items on his survey included the ability to: develop an understanding and sensitivity that appreciates differences and similarities; incorporate students' responses into lessons; and encourage students to respond using higher order questioning. He emphasized the most significant skills for working with ELLs saying,

Directness and improved clarity. I have a tendency of to ask circular logic per say but indirect questions, which may be helpful for more advanced students to broaden their knowledge and make them think deeper about the material. For the students that I teach and for ESL kids in particular, direct questions are going to help me get more out of what we're learning. So I have to watch myself on that and change what I do...understanding that increasing wait time when you ask a question. Most of your population is going to need 10-30 seconds to think about any advance question that you're going to ask them rather than just a yes/no question. For an ESL kid, its going to take maybe an extra 10 seconds to process the language component added on to that wait time to think about the content of it before they respond. I think Knowing and Learning affected me for the ESL kids. We went over strategies to help our ESL students and things like giving them previews, translated documents so that they get to see the material in both languages so that they don't have to miss out in any of the content just because they don't speak English as well as their classmates (Matthew Thompson, Interview, March 30, 2011).

Here, Matthew commented on the crucial ways that improved his teaching for ELLs attributed the knowledge gained from pre-service coursework even if they were not directly related to obtaining ESL certification. That preparation enabled him to practice the skill of wait time and higher-order questioning so that his ELLs gained access the content with a deeper level of understanding.

The case of Timothy Jones displayed not only an instructional strength with CREDE standard one of joint productivity but also how his efficacy could have been improved from the social influence of the school setting as a first year teacher (Woolfolk \& Spero, 2005). Frequent opportunities for peer interaction were noted to support students in using new vocabulary as evident within the measurement lesson when students participated in think/pair/share activities as well as hand-on materials with rulers, paper, yardstick that occurred during his classroom observation. However, Timothy noted that those teaching practices were a response from a certain strategy that he learned from the teaching program saying,

I learned the concept of scaffolding from them [Alternative Certification Program]. But there wasn't classes on multiculturalism that helped me to teach...Besides really the general instruction education that I got, there wasn't anything that I can recall that I really implemented specific for ELLs (Timothy Jones, Interview, March 24, 2011).

Timothy emphasized that drawing on practices that reflected scaffolding techniques learned within initial licensure are critical, however, in order for him to feel more efficacious, specific courses that outline more specific ESL pedagogy would influence his ability with greater mastery. Thus, as a new teacher, the context where this learning would have occurred is within professional development opportunities which function as a powerful social influence to practice and master techniques alongside grade-level teachers, more experienced professionals, and other specialists (Freeman \& Johnson, 1998).

Finally, the case of Lulu Martinez accentuated the benefits of social influences such as the participation with in-service experiences that enabled her to feel more confident in teaching ELLs. She indicated that her participation in the district's ESL Academy had made the biggest impact and developed her efficacy with pedagogical awareness for ELLs saying,

I think that the ESL Academy here in the district made it more personal. I think that it's just slowing down, annunciating, or articulating your words where they can understand. Give them time to respond back. I use my 
hands to teach all the time_-TPR. I have learned so much. I understood my culture but really it was through the ESL Academy here [not college]. I would say what I had (in college) was very brief. At Westside University (pseudonym), it was more focused on general-ed. I didn't know that going into the program. I should have done some more investigating, but my certification is just EC-4 for general education. They did offer 2 multiculturalism classes but I only took one because I only needed one to fill my coursework. (Lulu Martinez, Interview, March 31, 2011).

The comments detailed how Lulu's competency was acquired from the knowledge and skills learned from the ESL certification classes rather than pre-service courses; therefore, reinforcing the demand for embedded ESL pedagogy within preparation experiences to improve teachers' efficacy where novice teachers have the opportunity for meaningful practice of content pedagogical knowledge (Freeman \& Johnson, 1998; Grossman, 1990; Shulman, 1987).

\section{Discussion}

Data analysis from the survey, classroom observations, and interviews among the five cases aforementioned indicated that specific courses and trainings around ESL methodologies in pre-service contexts greatly influenced teachers' efficacy. The three cases of Antonia Perez, Thelma Smith, and Matthew Thompson permeate to show how quality preparation experiences honed teaching practices that translated from roles of learner abilities to efficacious behaviors with positive visions for ELL students (Coady, Harper, \& deJong, 2011; Feiman-Nemser, 2001; Kennedy, 1991). Two additional cases from Timothy Jones and Lulu Martinez extended the discourse of preparation and efficacy by disclosing the impact of supporting teachers' knowledge, skills, and dispositions learned within the context of initial licensure (Gandara et al., 2005).

Findings from this study stress the importance in preparing teachers to obtain initial licensure with ESL infused coursework as a crucial element in the process of promoting positive efficacy in working with ELLs. Because preparation programs vary widely in states and districts, it is important to note the best organization of courses so that they provide meaningful content, theories of language acquisition, and teaching strategies for ELLs. Coursework should also provide candidates opportunities for diverse settings and field experiences (Cochran-Smith \& Zeichner, 2005) to work directly with ELLs (Gandara et al., 2005; Lucas et al., 2008). These experiences become incredibly meaningful shaping teacher development from pre-service preparation to practice bolstering confidence and efficacy.

Finally, the five cases revealed how individual teachers embodied a clear understanding of particular ESL strategies implemented in the context of their classroom for appropriate adaptations in fulfilling the academic needs of ELLs (Schleppergrell, 2004). Each case worked to reduce affective filters in the classroom to ensure that ELLs felt comfortable (Krashen, 2003) and scaffolds with student interaction were noted widely in the examples of flexible grouping and/or pairing strategies facilitated by these teachers during their lessons. Moreover, these teachers were aware of their student's linguistic strengths to facilitate and enhance ELL's English academic success. Teachers were conscious in recognizing students' language differences as developmental progress helping students to produce both social and academic language. And finally, Antonia, Thelma, Matthew, Timothy, and Lulu crafted instructional decisions derived from their preparation experiences that allowed for support in language and content where cultural and linguistic factors were valued, respected, and enriched for student's understanding of the lesson objectives (Ballantyne et al., 2008).

\section{Conclusion}

This study sheds light into a topic that has been least explored in the literature regarding teachers' perceptions and efficacy beliefs for working with ELLs in the United States and abroad. Continued research is necessary in this topic to determine how new and existing teachers feel in their preparation experiences and efficacy for planning and delivering instruction to their ELL students. We have learned from this study how efficacy equips teachers well to work with ELLs echoed by few recent studies (Coady et al., 2011; Faez \& Valeo, 2012); therefore, widening efforts by all stakeholders working with pre-service and in-service teachers to promote teachers' abilities should be prioritized in preparation programs ensuring the necessary change to serve ELLs confidently.

Research on teacher candidates' field experiences and student teaching internship warrant another concern regarding best approaches in preparing future teachers for ELLs. Integrated field experiences that provide direct contact for candidates to work with ELLs may be helpful to determine the impact of applicable tools learned for ELLs (Cochran-Smith \& Zeichner, 2005). A longitudinal study on pre-service teacher candidates during their preparation coursework related to ESL methodologies and following teacher candidates through their first years of teaching could provide a lens to examine this progress. 
Finally, the findings presented in this study suggest the need for teacher education programs across the United States and internationally to embed required ESL coursework material to pre-service teacher candidates preparing them for initial certification to work with ELLs. While some states already mandate these courses, continued dialogue is desirable across universities and agencies to develop consistent frameworks and policies (Athanases \& Oliveira, 2011). Thus, research is needed in how coursework experiences promote reflective dialogue between fieldwork experiences to emphasize how educational policies and practices are carried out in the context of language, class, and race ideologies for pre-service teachers. Finally, ongoing discourse should describe the benefits of an ESL integrated approach for teachers working with ELLs and how preparation programs have improved teachers' understandings and competencies for praxis of social change.

By surveying American teachers' perceptions and efficacy beliefs from their pre-service and in-service experiences, I have attempted to show how an ESL certification plays a significant role in supporting five teachers' abilities to work successfully with ELLs given specific ESL practices that were learned to exemplify CREDE's standards. While in-service experiences were important for teachers, infused ESL coursework during initial licensure was most profound in developing high efficacy ratings for working with ELLs. This allowed the five teachers who were profiled to support students' acquisition of English proficiency in a classroom environment that bridges culture, content, and language while engendering academic success.

\section{References}

Abedi, J., Courtney, M., \& Leon, S. (2003). Effectiveness and validity of accommodations for English language learners in large-scale assessments (CSE Technical Report No. 608). Los Angeles, CA. National Center for Research on Evaluation, Standards, and Student Testing. Retrieved from http://www.cse.ucla.edu/products/ rsearch.asp

American Association for Employment in Education. (2005). Educator Supply and Demand in the United States. Retrieved from http://www.aaee.org/cwt/external/wcpages/files/2005execsummaryfinal.pdf

Antunez, B. (2002). The preparation and professional development of teachers of English language learners. ERIC Digest. Washington D.C.: ERIC Clearinghouse on Teaching and Teacher Education. (ERIC Document Reproduction Service No. ED 477724).

Athanases, S. Z., \& Oliveira, L. C. (2011). Toward program-wide coherence. In T. Lucas (Ed.), Preparing teacher for linguistically diverse classrooms. A resource for teacher educators (pp. 195-215). New York, NY: Routledge/Taylor \& Francis.

Ballantyne, K. G., Sanderman, A. R., \& Levy, J. (2008). Educating English language learners: Building teacher capacity. Washington, DC: National Clearinghouse for English Language Acquisition. Retrieved from http://www.ncela.gwu.edu/files/uploads/3/EducatingELLsBuilding Teacher Capacity Vol1.pdf

Bandura, A. (1997). Self-efficacy: The exercise of control. New York: Freeman.

Bem, D. J. (1972). Self-perception theory. In L. Berkowitz (Ed.), Advances in Experimental Social Psychology (Vol. 6, pp. 1-62). New York: Academic Press.

Center for Research on Education, Diversity, and Excellence. (2002). A National Study of Teacher Education Preparation for Diverse Student Populations. Retrieved from http://gse.berkeley.edu/research/credearchive/ research/pdd/2.1es.html

Coady, M., Harper, C., \& deJong, E. (2011). From preservice to practice: Mainstream elementary teacher beliefs of preparation and efficacy with English language learners in the state of Florida. Bilingual Research Journal, 34(2), 223-239. http://dx.doi.org/10.1080/15235882.2011.597823

Cochran-Smith, M., \& Zeichner, K. (2005). Studying teacher education. Mahwah, NJ: Lawrence Erlbaum.

Combs, M. C., Evans, C., Fletcher, T., Parra, E., \& Jimenez, A. (2005). Bilingualism for the children: Implementing a dual-language program in an English-only state. Educational Policy, 19(5), 701-728. http://dx.doi.org/10.1177/0895904805278063

Council of Chief State School Officers (2011). In TASC model core teaching standards: A resource for state dialogue. Retrieved from http://www.ccsso.org/Documents/2011/InTASC_Model_Core_Teaching Standards_2011.pdf

Creswell, J. W. (2003). Research design: Qualitative, quantitative, and mixed methods approaches (2nd ed.). Thousand Oaks, CA: Sage. 
Cummins, J. (2000). Language, power, and pedagogy: Bilingual children in the crossfire. Clevedon, UK: Multilingual Matters.

De Jong, E. J., \& Harper, C. A. (2005). Preparing mainstream teachers for English language learners: Is being a good teacher good enough? Teacher Education Quarterly, 32(2), 101-124.

Echevarria, J., Vogt, M., \& Short, D. J. (2004). Making content comprehensible for English language learners: The SIOP model (2nd ed.). Boston: Allyn \& Bacon.

Enderlin-Lampe, S. (2002). Empowerment: Teacher perceptions, aspirations and efficacy. Journal of Instructional Psychology, 29(3), 139-146. Retrieved from http://www.edweek.org/ew/articles/2010/11/10/ 11pd_ell.h30.html?r=693430799

Faez, F., \& Valeo, A. (2012). TESOL teacher education: Novice teachers' perceptions of their preparedness and efficacy in the classroom. TESOL Quarterly, 46(3), 450-471. http://dx.doi.org/10.1002/tesq.37

Feiman-Nemser, S. (2001). From preparation to practice: Designing a continuum to strengthen and sustain teaching. Teachers College Record, 103(6), 1013-1055. http://dx.doi.org/10.1111/0161-4681.00141

Freeman, D., \& Johnson, K. (1998). Reconceptualizing the knowledge-base of language teacher education. TESOL Quarterly, 32(3), 397-417. http://dx.doi.org/10.2307/3588114

Gandara, P., Maxwell-Jolly, J., \& Driscoll, A. (2005). Listening to teachers of English language learners. Retrieved from http://www.cftl.org/centerviews/july05.pdf

Goddard, R. D., Hoy, W. K., \& Woolfolk, H. A. (2004). Collective efficacy beliefs: Theoretical developments, empirical evidence, and future directions. Educational Researcher, 33(3), 3-13. http://dx.doi.org/10.3102/ 0013189X033003003

Grant, E. A., \& Wong, S. D. (2003). Barriers to literacy for language-minority learners: An argument for change in the literacy education profession. Journal of Adolescent and Adult Literacy, 46(5), 386-394. http://dx.doi.org/10.1598/JAAL.46.5.2

Grossman, P. L. (1990). A study in contrast: Sources of pedagogical content knowledge for secondary English. Journal of Teacher Education, 40(5), 24-31.

Hattie, J. (1992). Self-concept. Hillsdale, NJ: Lawrence Erlbaum.

Irvine, J. J. (2003). Educating teachers for diversity: Seeing with a cultural eye. New York: Teachers College Press.

Kaplan, S., \& Leckie, A. (2009). The impact of English-only legislation on teacher Professional development: Shifting perspectives in Arizona. Theory into Practice, 48(4), 297-303. http://dx.doi.org/10.1080/ 00405840903192896

Karabenick, S. A., \& Noda, P. A. C. (2003). Professional development implications of teachers' beliefs and attitudes toward English language learners. Bilingual Research Journal, 28, 55-75. http://dx.doi.org/10.1080/15235882.2004.10162612

Kennedy, M. (1991). An agenda for research on teacher learning (National Center for Research on Teacher Learning Special Report). East Lansing: Michigan State University.

Kindler, A. L. (2002). Survey of the states' limited English proficient students and available educational programs and services 2000-2001 summary report. Washington, DC: National Clearinghouse for English Language Acquisition.

Krashen, S. D. (1985). The input hypothesis: Issues and implications. London: Longman.

Krashen, S. D. (2003). Explorations in language acquisition and use. Portsmouth, NH: Heinemann.

Lortie, D. (1975). School teacher: A sociological study. Chicago: University of Chicago Press.

Lucas, T., Villegas, M., \& Freedson-Gonzalez, M. (2008). Linguistically responsive teacher education: Preparing classroom teachers to teach English language learners. Journal of Teacher Education, 59(4), 361-373. http://dx.doi.org/10.1177/0022487108322110

Merriam, S. B. (1988). Case study research in education: A qualitative approach. San Francisco: Jossey-Bass.

National Center for Education Statistics. (2002). Schools and staffing survey: 1999-2000. Retrieved from http://nces.ed.gov/pubs2002/2002313.pdf 
National Center for Education Statistics. (2014). Digest of Education Statistics 2013. Retrieved from http://nces.ed.gov/programs/digest/d13/tables/dt13_204.20.asp

National Council of Accreditation for Teacher Education. (2009). Standards for the recognition of initial TESOL programs in P-12 ESL teacher education. Retrieved from http://www.tesol.org/docs/books/ the-revised-tesol-ncate-standards-for-the-recognition-of-initial-tesol-programs-in-p-12-esl-teacher-educatio n-\%282010-pdf\%29.pdf?sfvrsn=0

O'Neal, D., Ringler, M., \& Rodriguez, D. (2008). Teachers' perceptions of their preparation for teaching linguistically and culturally diverse learners in rural eastern North Carolina. The Rural Educator, 30(1), $5-13$.

Quezada, R., \& Alfaro, C. (2012). Moving pedagogical mountains: Cutting to the common core. Language Magazine, 11(12), 19-22.

Samway, K., \& McKeon, D. (2007). Myths and realities: Best practices for English language learners (2nd ed.). Portsmouth, NH: Heinemann.

Schleppegrell, M. J. (2004). The language of schooling: A functional linguistics perspective. Mahwah, NJ: Lawrence Erlbaum.

Shulman, L. S. (1986). Those who understand: Knowledge growth in teaching. Educational Researcher, 15(2), 4-14. http://dx.doi.org/10.3102/0013189X015002004

Shulman, L. S. (1987). Knowledge and teaching: Foundations for the new reform. Harvard Educational Review, 57(1), 1-22. http://dx.doi.org/10.17763/haer.57.1.j463w79r56455411

Stein, M., \& Wang, M., (1988). Teacher development and school improvement: The process of teacher change. Teaching and Teacher Education, 4(2), 171-187. http://dx.doi.org/10.1016/0742-051X(88)90016-9

Tabachnick, B., Zeichner, R., \& Kenneth, M. (1993). Preparing teachers for cultural diversity. Journal of Education for Teaching, 19(2), 113-125. http://dx.doi.org/10.1080/0260747930190412

Taylor, S. V., \& Sobel, D. M. (2001). Addressing the discontinuity of students' and teachers' diversity: A preliminary study of preservice teachers' beliefs and perceived skills. Teaching and Teacher Educator, 17(4), 487-503. http://dx.doi.org/10.1016/S0742-051X(01)00008-7

Teachers of English Speakers of Other Languages. (2010). TESOL/NCATE standards for the recognition of initial TESOL programs in P-12 teacher education. Alexandria, VA: Author.

Tellez, K., \& Waxman, H. (2005). Quality teachers for English language learners. The Laboratory for Student Success at Temple University Center. Retrieved August 20, 2010, from http://www.temple.edu/lss

Tshannen-Moran, M., Woolfolk, H. A., \& Hoy, W. K. (1998). Teacher efficacy: Its meaning and measure. Review of Educational Research, 68(2), 202-248. http://dx.doi.org/10.3102/00346543068002202

Verplaetse, L. S., \& Migliacci, N. (2008). Making mainstream content comprehensible through sheltered instruction. In L. S. Verplaetse, \& N. Migliacci (Eds.), Inclusive pedagogy for English language learners: A handbook of research-informed practices (pp. 127-165). New York: Lawrence Erlbaum.

Vygostsky, L. (1978). Mind in society. Cambridge, UK: Cambridge University Press.

Walqui, A. (2008). The development of teacher expertise to work with adolescent English learners: A model and a few priorities. In L. S. Verplaeste, \& N. Migliacci (Eds.), Inclusive pedagogy for English language learners: A handbook of research-informed practices (pp. 103-125). New York: Lawrence Erlbaum.

Wood, D., Bruner, J., \& Ross, G. (1976). The role of tutoring in problem solving. Journal of Child Psychology, 17(2), 89-100. http://dx.doi.org/10.1111/j.1469-7610.1976.tb00381.x

Woolfolk, H. A. E., Rosoff, B., \& Hoy, W. K. (1990). Teachers' sense of efficacy and their beliefs about managing students. Teaching and Teacher Education, 6(2), 137-148. http://dx.doi.org/10.1016/ 0742-051X(90)90031-Y

Woolfolk, H. A., \& Spero, R. B. (2005). Changes in teacher efficacy during the early years of teaching: A comparison of four measures. Teaching and Teacher Education, 21(4), 343-356. http://dx.doi.org/10.1016/ j.tate.2005.01.007

Wong-Fillmore, L., \& Snow, C. (2005). What teachers need to know about language. In C. T. Adger, C. E. Snow, \& D. Christian (Eds.), What teachers need to know about language (pp. 7-54). Washington D. C.: Center for Applied Linguistics. 
Yin, R. (2008). Case study research (4th ed.). Thousand Oaks, CA: Sage.

\section{Copyrights}

Copyright for this article is retained by the author(s), with first publication rights granted to the journal.

This is an open-access article distributed under the terms and conditions of the Creative Commons Attribution license (http://creativecommons.org/licenses/by/3.0/). 